\title{
研究
}

論文脱血流量制御器“トリプルフロー”の考案

東京女子医科大学付属日本心臓血圧研究所 人工心肺室

鈴木進風間茂

佐々木 章涌 井好二

同 循環器外科

遠 藤 真 弘 小 柳 仁

I .はじめに

生体より人工心肺への静脈血導入には, ポンプ 脱血法, サイホンの原理を用いた落差脱血法があ る. 今回, 我々は, 落差脱血法を用いた体外循環 時に人工心肺への移行時および離脱時などに脱血 流量の段階的増加，減少を確実かつ容易に制御で きる落差脱血流量制御器（以下,トリプルフロー） を考案したので報告する（写真 1 ）.

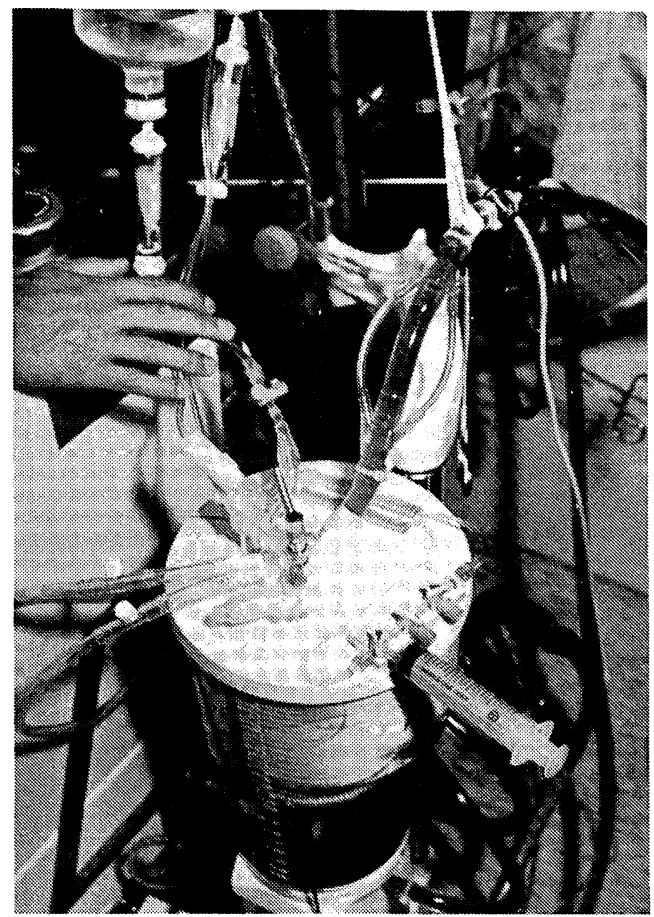

写真 1
II . トリプルフローの形状および使用方法

形状は, 脱血回路主導管に，2 本の細いバイパ ス管（以下，側管）をむつ簡単な構造で，流量制 御方法は，主導管および 2 本のバイパス管をチュ

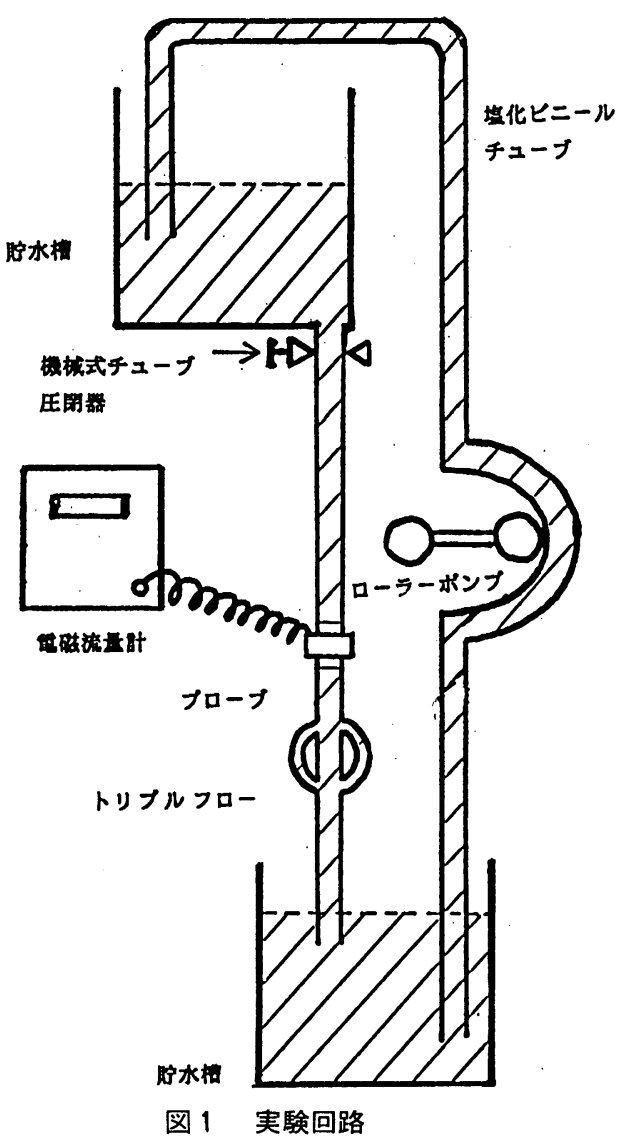


ーブ鉗子で開閉させることにより行うあのである (図 1).

また，試作に先立ち成人体外循環での使用を前 提とした諸条件を定めるため, 当研究所での冠動 脈バイパス術施行 100 症例の平均体重, 平均体外 循環灌流量および手術時の心房より人工肺静脈眝 血槽液面上部までの平均落差高を調べた。 その結 果, 平均体重は $62 \pm 9 \mathrm{~kg}$, 平均体外循環灌流量は $3720 \pm 540 \mathrm{~m} \ell / \mathrm{min}$, 平均落差高は $50 \mathrm{~cm}$ であった.

これからの結果より, トリプルフロー製作条件は落 差高 $50 \mathrm{~cm}$ における最大脱血流量 $4 \pm 1 \mathrm{ml} / \mathrm{min}$ で の流量制御とした. 流量制御量は, 主導管を閉じ て60\%，さらに側管を 1 本閉じることにより $30 \%$ の流量を得ることができれば, 実用上問題はない， 之考え, 実験検討の結果主導管部は内径 $1 / 2$, 側 管部は内径 $3.1 \mathrm{~mm}$ の 2 本とした.

\section{III. 実験方法}

\section{1. 実験回路}

$100 \mathrm{~cm}, 75 \mathrm{~cm}$ ，および $50 \mathrm{~cm}$ の落差を設定できる ように上下の貯水槽を内径 $1 / 2$ の管で接続し, 途 中に日本光電工業製電磁血流量計 F F - 012 T体

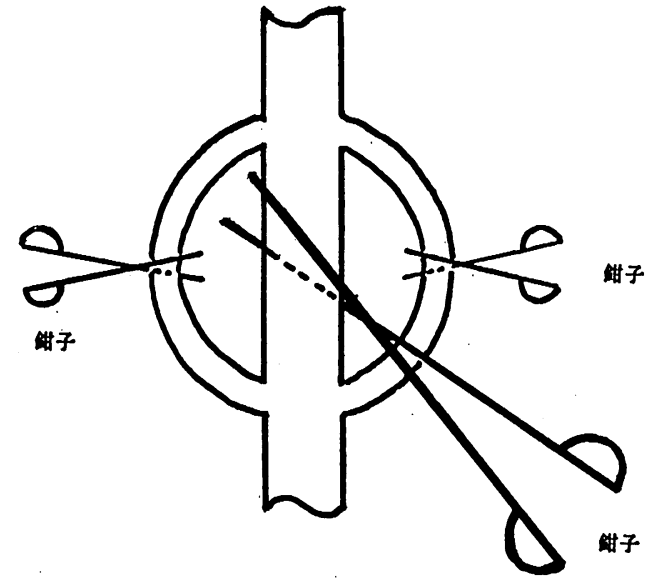

図 2 トリプルフローの形状

外型（以下, 流量計）およびトリプルフローを挿 入した. 挿入位置としてはトリプルフローは下部 貯水槽液面より $30 \mathrm{~cm}$ 上方, さらに $5 \mathrm{~cm}$ 上方に流量 計を設置した（図 2 ）。

なお，流体は生理食塩水を用い常温下で行い， 再循環方式にて行った。

\section{2. 流量およひ落差設定}

$3 ， 4$, および $5 \ell / \min$ の各流量設定は，下

\section{表 1 実験結果}

流量 $3 \ell / \mathrm{min}$

\begin{tabular}{r|cr|cr} 
& \multicolumn{2}{|c|}{$3.1 \mathrm{~mm} \times 2$} & \multicolumn{2}{|c}{$3.1 \mathrm{~mm}$} \\
\hline 落差 $50 \mathrm{~cm}$ & \multicolumn{2}{|c|}{$1690 \mathrm{ml} / \mathrm{min}(56,3 \%)$} & $960 \mathrm{ml} / \mathrm{min}(32,0 \%)$ \\
\hline $75 \mathrm{~cm}$ & 2060 & $(68,7)$ & 1290 & $(43,0)$ \\
\hline $100 \mathrm{~cm}$ & 2100 & $(70,0)$ & 1360 & $(45,3)$
\end{tabular}

流量 4 l / $\mathrm{m} \mathrm{i} \mathrm{n}$

\begin{tabular}{r|rr|rr} 
& \multicolumn{2}{|c|}{$3.1 \mathrm{~mm} \times 2$} & \multicolumn{2}{|c}{$3.1 \mathrm{~mm}$} \\
\hline 落差 $50 \mathrm{~cm}$ & $1820 \mathrm{ml} / \mathrm{min}(45,5 \%)$ & $1000 \mathrm{ml} / \mathrm{min}(25,0 \%)$ \\
\hline $75 \mathrm{~cm}$ & 2350 & $(58, .8)$ & 1360 & $(34,0)$ \\
\hline $100 \mathrm{~cm}$ & 2420 & $(60,5)$ & 1450 & $(36,3)$
\end{tabular}

流量 $5 \ell / \mathrm{min}$

\begin{tabular}{r|cr|cr} 
& \multicolumn{2}{|c|}{$3.1 \mathrm{~mm} \times 2$} & \multicolumn{2}{|c}{$3.1 \mathrm{~mm}$} \\
\hline 落差 $50 \mathrm{~cm}$ & $1910 \mathrm{ml} / \mathrm{min}(38,2 \%)$ & $1000 \mathrm{ml} / \mathrm{min}(20,0 \%)$ \\
\hline $75 \mathrm{~cm}$ & 2530 & $(50,6)$ & 1390 & $(27,8)$ \\
\hline $100 \mathrm{~cm}$ & 2600 & $(52,0)$ & 1500 & $(30,0)$
\end{tabular}


部眝水槽より Sarns 社製 7000-MDX Blood Pu$\mathrm{mp}$ を用いて上部貯水槽へ汲み上げ，上部貯水槽 流出部を機械式チューブ圧閉器を用いて流出量お よび液面の一定化を図った。

\section{3. 測定方法}

測定は50，75および $100 \mathrm{~cm}$ の落差の条件下に最 大流出量 $3 ， 4$ および $5 \ell / \min$ でのそれぞれで の流量変化を測定した.
流量減少測定は，最初に主導管を鉗子で閉じ， 続いて片方の側管を閉じ測定した．流量増加測定 は全部を閉じた状態より片方づつ側管を開放し， 最後に主導管を解放して測定した（表 1 ）。

\section{IV. 臨床使用}

臨床使用は, 冠動脈バイパス術 8 症例, A S D 2 症例に用いた。人工心肺装置はトノクラ医科工

\section{表 2 臨床使用結果}

\begin{tabular}{|c|c|c|}
\hline \multirow[t]{2}{*}{ (1)体重 $63 \mathrm{~kg}$} & \multicolumn{2}{|c|}{ 平均体外㡒理竞流量 $3800 \mathrm{~m} \mathrm{l} / \mathrm{mi} \mathrm{n}$} \\
\hline & 3. $1 \mathrm{~mm} \times 2$ & 3. $1 \mathrm{~mm}$ \\
\hline 体外堦璒移行時 & $1800 \mathrm{ml} / \mathrm{min}(47,4 \%)$ & $1000 \mathrm{ml} / \min (26,3 \%)$ \\
\hline 体外循環離脱時 & $(44,7)$ & $(21,0)$ \\
\hline
\end{tabular}

(2)体重 $53 \mathrm{~kg}$ 平均体外偱棵逗流量 $3200 \mathrm{~m} \mathrm{l} / \mathrm{m} \mathrm{i} \mathrm{n}$

\begin{tabular}{|c|c|c|}
\hline & 3. $1 \mathrm{~m} \mathrm{~m} \times 2$ & 3. $1 \mathrm{~m} \mathrm{mn}$ \\
\hline 体外復棵移行時 & $1500 \mathrm{ml} / \mathrm{min}(46,9 \%)$ & $900 \mathrm{ml} / \min (28,1 \%)$ \\
\hline 体外循 & $(56,2)$ & $(28,1)$ \\
\hline
\end{tabular}

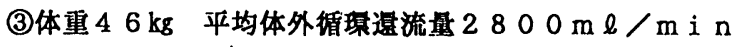

\begin{tabular}{|c|c|c|c|}
\hline & 3. $1 \mathrm{~m}$ & $n \times 2$ & 3. $1 \mathrm{~mm}$ \\
\hline 体外㖧懪移行時 & $2000 \mathrm{ml} / \mathrm{mi}$ & $(71,4 \%)$ & $1000 \mathrm{ml} / \min (35,7 \%)$ \\
\hline 体外循䜊霅 & 2100 & $(75,0)$ & $(39,3$ \\
\hline
\end{tabular}

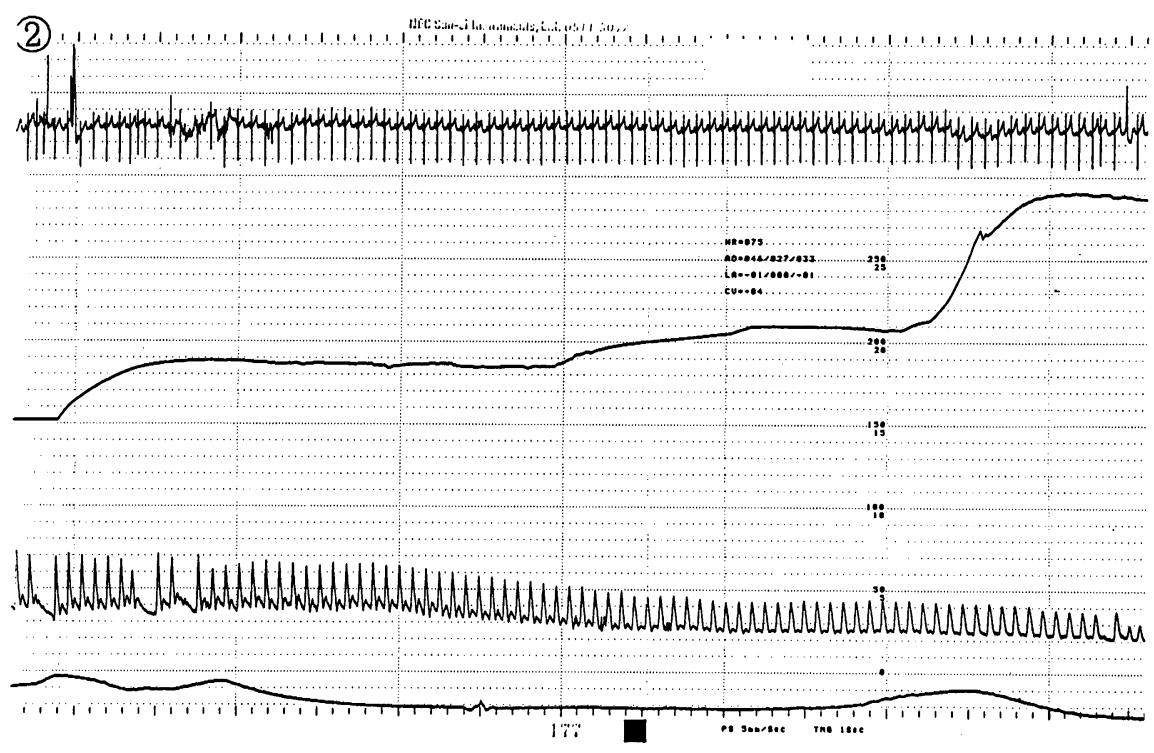

図 3 臨床使用結果（移行時） 


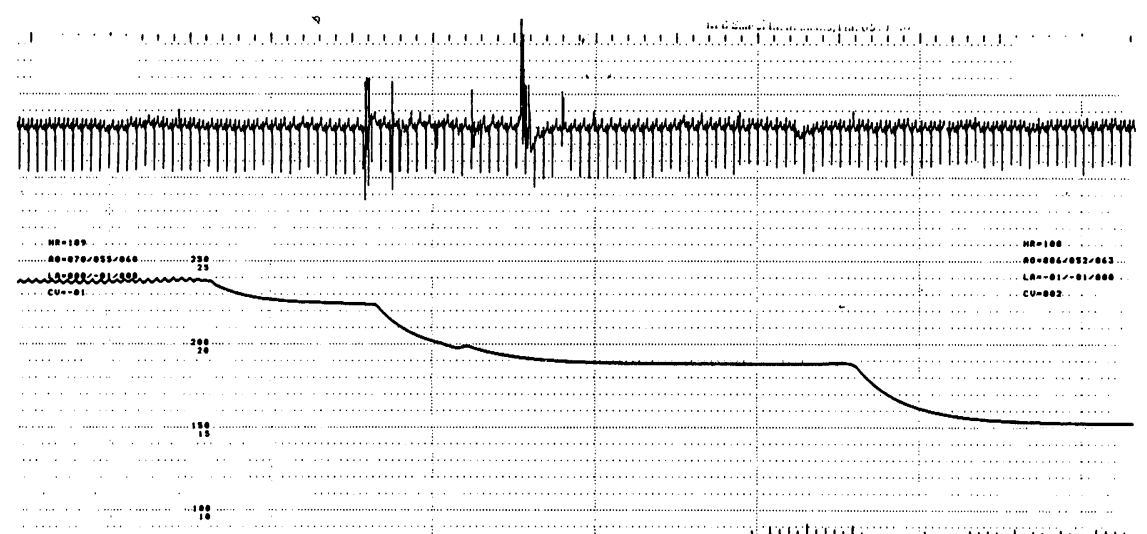

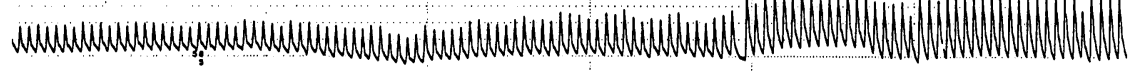

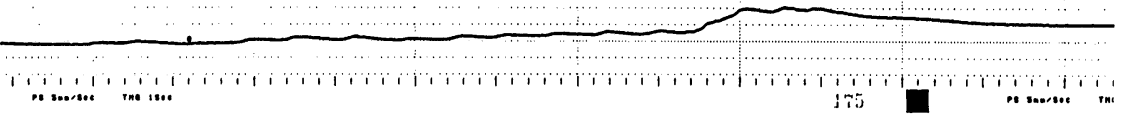

図 4 臨床使用結果（離脱時）

業社製冷温水槽内蔵コンポーネントタイプ, 人工 肺はCOBE 社製 I FCML 型人工肺を使用した。

トリフローは，操作がしやすいよう人工肺静脈 流入部近位に挿入, 流量計は患者とトリプルフローの 間に挿入した。体外循環開始と同時に側管の一本 を開放，次にもう一方の側管を開放させ最後に主 導管を解放して，予定灌流量に必要な脱血量が得 られた。人工心肺より離脱過程では，開始時と逆 の手順で主導管を閉め, さらに側管を閉めて離脱 した. この間, 流量計で確認すると共に, 日本電 気三栄社製ポリグラフ，モデル 363 の記録計で記 録した（表 2 , 図 3，4）。

\section{V. 考 察}

落差脱血はポンプ脱血法に比べ操作が容易で, 人工心肺回路が簡素などの点から一般に用いられ ている. 現行の流量制御法では, 簡単な器具を手 動あるいは電動でチューブを狭窄させるチューブ 圧閉方式, 人工肺を上下させ生体との落差を変化 させる昇降式，あるいは，ただ単にチューブ鉗子 で挾み流量を制御する方法が一般的と思われる。 しかし，いずれも熟練や器具機材を必要とし，初 心者などは送脱血のバランスを崩す場合むある. 落差脱血による体外循環に，トリプルフローを用いる
ことで人工心肺操作を容易にした。構造が簡単で 誰にでも同じように使用でき，操作技術差がなく なり安定した体外循環への移行・離脱が可能とな った．単体ディスポーザブル化するととにより， 簡単に組み込みができ便利である. 落差高が50cm あればいかなる場合でも使用が可能であった。

現行型は, 落差 $50 \mathrm{~cm}$ で最大流量 $4 \pm \ell / \min$ で 製作しているが，主導管および側管の太さを変え るととで少流量での制御も可能と考える.

\section{VI. 結 語}

臨床使用では, 従来の流量調整方法に比べトリ プルフローは流量変化が分かっているため, 急激な流 量変化をおてす危険性がなく，送血流量とのバラ ンスが容易であった，操作に関してあ必要な部分 を鉗子で開閉するだけなので容易であった。 トリ プルフローを使用するととにより, 人工心肺操作を容 易かつ安全に行うことができた。 現在, 人工心鉗 回路に組み込み良好な結果が得られている.

なお, 本考案は第26回日本人工臟器学会 (1988 年 9 月 東京) に扔いて発表（口述のみ）した。 稿を終わるにあたり,トリプルフローの試作を引き受 けて頂いたトノクラ医科工業株式会社に深謝致し ます。 